\title{
MEASURING THE ENTREPRENEURIAL LEVEL OF THE BUSINESSMEN: THE RELATIONSHIP BETWEEN PERSONAL TRAITS AND ENTREPRENEURIAL LEVEL
}

\author{
Res. Assis. Dr. Burcu KÜMBÜL GÜLER, Dokuz Eylul University, Faculty of \\ Economics and Administrative Sciences, Labour Economics and Industrial \\ Relations, burcu.kumbul@deu.edu.tr \\ Prof. Dr. Mustafa Yaşar TINAR, Dokuz Eylul University, Faculty of Economics \\ and Administrative Sciences, Labour Economics and Industrial Relations, \\ yasar.tinar@deu.edu.tr
}

\begin{abstract}
With a focus of trait approach, the aim of this paper is to determine the personal characteristics of entrepreneurs that are related with their entrepreneurial drive level. The level of entrepreneurship is tried to be measured on a sample of 452 Turkish businessmen with the instrument of Carland Entrepreneurship Index CEI. For this study, a questionnaire consisted of somedemographical information about the businessmen, information about their enterprises, 5 instruments that are for measuring need for achievement, locus of control, risk taking behavior, innovativeness and CEI was designed. The questionnaires were delivered to all of the Turkish businessmen who are the members of Industrialists' and Businessmen's Association. With a return rate of $35 \%, 452$ questionnaires were evaluated for analysis. According to correlational analysis, other than internal locus of control, need for achievement, risk taking propensity and innovativeness showed strong interrelation within and with entrepreneurial level. According to the linear regression model, innovativeness, risk taking propensity, yearly revenue more than 1 million $\$$ compared to the revenue less than 1 million $\$$ and the reason of investment ("create employment, contribute to the country's economy, gain status/power" compared to "make profit/earn money") positively and significantly affect the entrepreneurial level of the businessmen.
\end{abstract}

Key Words: Entrepreneurship, Personality Traits, Entrepreneurial Level 


\section{INTRODUCTION}

Although there have been many attempts to define and explain what "entrepreneurship" is, no consensus definition has emerged (Carland, et al., 2001; 53). In a detailed explanation, Hisrich (1990; 210-211) defines entrepreneurship as a "process of creating something different with value by devoting the necessary time and effort, assuming the accompanying financial, psychic, and social risks, and receiving the resulting rewards of monetary and personal satisfaction". It is very difficult to give an exact definition of entrepreneurship and this debate affects to decide on who the entrepreneur is. Schumpeter (1934) considers entrepreneurs as the driving economic force behind a capitalist economy and stresses on the innovative personality while McClelland (1961) explains entrepreneurship as an expression of high need for achievement (cited in Johnson, 1990; 39) and offers a set of significant traits to explain entrepreneurial behavior. These traits are high need for achievement, moderate risk taking propensity, preference for energetic and/or novel activity, and assuming personal responsibility for successes or failure. Carland, et. al., (1984) distinguishes entrepreneurs from small business owners. An entrepreneur is innovative, employs strategic management practices and manages his business for the purpose of profit and growth. Bygrave and Hofer (1991; 14) provide a simple but impressive definition of an entrepreneur as "someone who perceives an opportunity and creates an organization to pursue it". In order to reach an agreement on the definition of "entrepreneur", we can give a widely accepted definition: "an entrepreneur is a self-motivated individual who takes the initiative to start and build an enterprise relying primarily on self rather than others to formulate and implement his or her goals" (Mueller and Thomas, 2000; 55). According to those definitions, we consider all of the businessmen having small to very large enterprises as entrepreneurs but their level of entrepreneurial drive may vary according to their personal characteristics and perspectives to their business. This kind of evaluation of the entrepreneurs oriented us to have a psychological approach to entrepreneurship studies.

The research of entrepreneurship has roots in economics, sociology and management; however psychological approach to this discipline was ignored until late 1990's. Brandstatter $(1997 ; 158)$ stresses on the fact that only very recently psychology started to deal with the personality of entrepreneurs and it was a neglected area of research. It was because most economists view that in order to explain entrepreneurial behavior; one ought not to take into account the personality structure of entrepreneurs, nor their motives besides their general interest in maximizing their profit. The researchers had the idea that the general economic conditions and the laws behind the economic processes would largely determine the entrepreneurs' position.

In order to establish the link of the psychology and entrepreneurship research, several psychologists and researchers have been trying to search the behavior and characteristics of the entrepreneurs and underlying human factors of 
entrepreneurship. Still today, there are calls for psychologists to illuminate the gaps in the entrepreneurship literature while developing theories on the personal characteristics of the entrepreneurs (Hisrich et al., 2007; 575). Following this advice, for this research, we asked "what are the distinctive personal characteristics of the entrepreneurs who are more successful than others?" (Baron, 2000; 15) which leads us to analyze the predictors of entrepreneurial level.

In search of the empirical studies involving the characteristics of entrepreneurs, it can be observed that these studies can both have an aim to associate various characteristics with entrepreneurship and use the characteristics to predict entrepreneurial performance (Chu, 2000; 68). In an important analysis of entrepreneur personality, Kets de Vries (1977) concludes that entrepreneurs have a particularly high need for achievement, autonomy, independence, and moderate risk taking propensity. According to a wide range of studies, entrepreneurs seem to have some common distinctive characteristics different from the non-entrepreneurs. In reviewing the findings, the following list can be derived: entrepreneurs seem to have a high need for achievement, creativity and initiative, they are risk takers and self-confident, have internal locus of control, need independence and autonomy, accomplish their tasks with great energy and commitment, and are persistent in pursuing their goals (SchmittRodermund, 2004; 499).

In the literature, we identified four dominant personality traits for explaining entrepreneurial personality. These are risk taking, achievement motivation (need for achievement), internal (locus of) control and innovativeness (Tuunanen, 1997; 17). First of these traits is "Propensity for Risk Taking", which is the earliest defined characteristic of entrepreneurship by Cantillion. He describes the entrepreneur as "an individual who assumed the risk for the enterprise". Also, Palmer $(1971 ; 37)$ proffers that risk assessment and risk taking are the primary elements of entrepreneurship. Because entrepreneurs face a number of different types of risks, which can be grouped into financial risk, career risk, family and social risk and finally psychic risk (Kuratko and Hodgetts, 1998; 106-108). However, though the entrepreneurs are exposed to many of the risks that are specified above, they have high tolerance for risk and they have the tendency to take risk in the name of having their own business. The tendency to take the risk or "risk taking propensity" can be explained as "individual's willingness to take risks in uncertain decision-making scenarios" (Stewart, et. al., 2003; 29). In Brockhaus's (1980; 513) terms, risk-taking propensity is "the perceived probability of receiving rewards associated with the success of a situation that is required by the individual before he will subject himself to the consequences associated with failure, the alternative situation providing less reward as well as less severe consequences than the proposed situation".

In the explanation of "need for achievement - nAch", individuals who are high in this trait are said to be moderate risk takers. The conceptual thinking over 
entrepreneurship focus on the risk concept which is more often taken by the entrepreneur than a manager since the environment for the entrepreneur is less uncertain and the entrepreneur possess the ultimate responsibility for decisions (Stewart, et. al., 2003). Ultimately, it can be stated that risk taking is a trait that distinguishes entrepreneurs from non-entrepreneurs and managers, which is a commonly accepted result in personality traits of entrepreneurship researches (Lumpkin and Erdogan, 2004; 27).

The second characteristic is "Need for Achievement". In an interview for Forbes in 1969, McClelland stated "We have spent twenty years studying just this (why one businessman succeeds and another fails)...not necessarily a better head of General Motors; I am talking about the man who starts a business" and he continued to declare that the distinctive characteristic is the individual's need for achievement. Need for Achievement, originated by Henry Murray, was studied extensively by David McClelland and his associates claiming that the nAch is the key to the success of small business owners. This claim led the subsequent researchers to study the achievement motive as a distinct psychological characteristic of entrepreneurs (Johnson, 1990; 40-41).

According to McClelland (1971; 110-111), individuals who are high in nAch are more likely to engage in tasks that have ahigh degree of individual responsibility for outcomes, require individual skill and effort, have a moderate degree of risk, and include clear feedback on performance than those who are low in nAch. Further, McClelland argues that entrepreneurial roles are characterized as having a greater degree of these task attributes than other careers; thus, it is likely that people high in nAch will be more likely to pursue entrepreneurial jobs than other types of roles. In their analysis of several studies, Rauch and Frese $(2000 ; 13)$ found an empirical support that entrepreneurs are higher in need for achievement than other populations. Hisrich (1986)'s study on the American and Irish women entrepreneurs, without comparing them with non-entrepreneurs, revealed certain inherent characteristics in both samples. Both groups of women were well educated, energetic, and motivated by achievement. In a similar study Jacobson (1993) investigated six female entrepreneurs who had left corporate jobs and found that achievement/success was the entrepreneurs' predominant value (cited in Pillis, 1997; 23). In a study of 97 Turkish entrepreneurs, need for achievement together with need for power were found to be determining factors on the motivation of earning more while founding the enterprises. In this study, it is also found that while the level of need for achievement is increasing, the propensity of entrepreneurial personality also increases (Ceylan and Demircan, 2002; 13).

Third is the concept of "Internal Locus of Control", which is used to identify potential successful entrepreneurs by entrepreneurship researchers. Locus of control is a concept from Rotter's (1966) social learning theory. According to Rotter, individuals perceive the outcome of events as being either within or beyond their personal control and understanding (Mueller and Thomas, 2000; 
55-56). People with an internal locus of control, who perceive the events within their control, believe in themselves to be in control of their destiny. People with an external locus of control, who consider the events beyond their control, believe they are under the control of others, fate and chance (Rauch and Frese, 2000; 14; Mueller and Thomas, 2000; 56). As a consequence of the clarification of this personal trait, it might be assumed that entrepreneurs have internal locus of control since an entrepreneur is more likely to carry out his/her plans in business and to take action towards venture creation. While many of the studies have parallel results with this assumption, some of them are not consistent with it.

The identification of internal locus of control as a possible entrepreneurial trait spurred numerous empirical studies. Early studies during the 1970s showed generally positive findings (Jennings and Zeithaml, 1983; 419). For example, Borland found in a sample of 375 business school students that those students who expected to start a company someday had a stronger belief in internal control (Borland, 1974 cited in Mueller and Thomas, 2000; 56). Brockhaus found that business students with entrepreneurial intentions tended to have a higher internal locus of control than those who did not have such intentions (Brockhaus, 1975). In the study of Bonnett and Furnham (1991), 190 British adolescents who wanted to become entrepreneurs had a more internal locus of control and a strong belief in hard work than a controlgroup. In a study of 47 Turkish entrepreneurs, locus of control was found to be positivelycorrelated with entrepreneurial potential (Alpkan et al, 2002; 10). These studies reveal that internal locus of control is a positively associated trait with entrepreneurial success.

An individual with an internal locus of control believes that his or her life outcomes are the result of internal factors such as hard work. In order to justify the association between entrepreneurial behavior and internal locus of control, it can be claimed that if an individual do not believe that s/he can competently change the situation, s/he will be unlikely to embark on a project like venture creation (Pillis, 1997; 35). In Borland's (1974) study, in which the relationship between nAch, locus of control and entrepreneurial activities were investigated, the results revealed that entrepreneurs had a high nAch and an internal locus of control (cited in Jennings and Zeithaml, 1983; 419). Hull et al. (1980) concluded in their study with respect of predicting likelihood to start a business, $n$ Ach and internal locus of control are not the most important variables.

The last trait is the "Innovativeness", a trait that characterizes entrepreneurship which has often been shown to have a significant effect on venture performance (Rauch and Frese, 2000; 26). Entrepreneurs in an ever changing environment have to be ready to try out new ideas and to respond flexibly to changes around them (Brandstatter, 1997; 163), which are the main characteristics of an innovative person. Accordingly, West and Farr (1990) define innovation as "the intentional introduction and application... of ideas, process, products or procedures, new to the relevant unit of adoption" (cited in Utsch and Rauch, 
$2000 ; 48)$. Apart from the above personality traits, much of the entrepreneurship literature is about the entrepreneur's inclination and ability to innovate. In fact, to create and innovate are the conditions inherent in the role of entrepreneurship and they clearly separate the entrepreneurs from managers. Especially, Schumpeter (1934) emphasizes on the innovativeness of the entrepreneur and experimentation with new combinations by describing the entrepreneurs as introducing new products or methods of production, opening new markets or new sources of supply (cited in Chu, 2000; 68; Stewart, et. al., 2003; 29). The results of the study by Utsch and Rauch (2000; 57 ) imply that innovativeness is a mediator between achievement orientation and venture performance and they suggest that entrepreneurs should be innovative and try as much as possible to improve their work procedures. In addition, they relate the innovativeness with achievement claiming that a business owner with high achievement orientation is a resource for the innovativeness of enterprise.

\section{PROCEDURE}

\subsection{Objective of the Study}

We try to find how do certain personal and demographical characteristics of entrepreneurs (risk taking propensity, need for achievement, locus of control, and innovativeness) influence entrepreneurial level and performance. In addition, "Do the businessmen, according to their enterprise success, differ in these personal characteristics?" is a question that is worth asking in this study. This kind of concern also exists in Short and Dunn's study $(2002 ; 1)$, who claim that if entrepreneurial behavior studies were pursued intensively and specific behaviors of entrepreneurial success could be identified, then these behaviors could be taught to potential entrepreneurs. For this reason, in this study, by analyzing the Turkish businessmen in terms of their traits and entrepreneurial level, we aim to clarify what kind of traits and behaviors are needed to be a successful entrepreneur, which in turn, may be a model for the people who have the will to found a business.

\section{2. Sample}

In this study, survey was used as the research method to gather information from the Turkish businessmen about their enterprises, personality and entrepreneurial level. For this reason, a questionnaire was designed that includes some demographical questions about the businessmen, about their enterprises, 5 instruments for measuring risk taking behavior, need for achievement, locus of control, innovativeness and Carland Entrepreneurship Index (CEl-in order to determine the entrepreneurship level of the businessmen). The questionnaires were delivered to all of the Turkish businessmen who are the members of Industrialists' and Businessmen's Association via fax. With a return rate of $35 \%, 452$ questionnaires $(96.7 \%$ men, 
MEASURING THE ENTREPRENEURIAL LEVEL OF THE BUSINESSMEN: THE RELATIONSHIP BETWEEN PERSONAL TRAITS AND ENTREPRENEURIAL LEVEL

$3.3 \%$ women) were evaluated for analysis. Additional demographical information is given in the results.

\section{3. Instruments}

The four personality traits were measured by related instruments; with a fivepoint scale ranging from 1-strongly agree to 5-strongly disagree. Detailed information about each of the instruments is given below.

\section{Risk Taking Propensity}

For measuring the propensity for risk taking, we used the 6 items of the instrument of uncertainty avoidance in Mueller and Thomas's (2000) study. Some of these items are: "I would prefer a stable position with a moderate salary to one with a higher salary but less security", "My main goal in life is to have a secure and steady job" and "I enjoy taking risks".

\section{Need for Achievement}

In order to measure the level of nAch, we used totally 12 items of nAch Scale. 9 of them are from the updated and expanded version of Need for Achievement Questionnaire (NAQ) developed by Mehrabian and Banks (1978) cited in Ibrayeva (1999). Some of the items used from that Questionnaire in this study are: "I would prefer a job which is important, difficult and involves a $50 \%$ chance of failure to a job which somewhat important but not difficult", "I am hesitant about making important decisions at work", "I have difficulty working in a new and unfamiliar situation", "I prefer a job which requires original thinking", "I perform best in competitive situations". In addition we used 3 items of Lee and Tsang's (2001) nAch scale.

Locus of Control

In this questionnaire, to measure the locus of control of the sample, we constructed a 6 item - entrepreneurial locus of control scale by utilizing from the scales of Rotter's (1966) Locus of Control Scale (cited in Mueller and Thomas, 2000; 75). Three of the items are: "When I get what I want, it is usually because I work very hard for it", "My life is determined by my own actions" and "Success in business is mostly a matter of luck".

\section{Innovativeness}

In order to measure the innovativeness level of the subjects, which has been consistently identified as one of the important characteristics of entrepreneurs, The Jackson Personality Inventory Manual (JPI) was used in the questionnaire. Adjectives on the instrument used to describe entrepreneurs which highly correlate with innovativeness include imaginative, inventive, enterprising, original, resourceful and farsighted. A high score on the JPI innovativeness scale indicates a preference for novel solutions to problems and an appreciation for original ideas. For this study, 8 items were adapted from the JPI innovativeness scale (cited in Mueller and Thomas, 2000; 75). Some of these 
items are: "I often surprise people with my novel ideas", "People often ask me for help in creative activities", "I obtain more satisfaction from mastering a skill than coming up with a new idea" and "I prefer work that requires original thinking".

Carland Entrepreneurship Index

The instrument selected to measure the level of entrepreneurship is the Carland Entrepreneurship Index (We got the permission to use the CEI from Jo Ann and James Carland). Carland, et. al., 1992 posited a perspective of entrepreneurship which treats the phenomenon as an individual drive and they developed and validated an instrument which measures the strength of that drive, the Carland Entrepreneurship Index, and demonstrated that entrepreneurial drive is normally distributed. Carland (2001) sees entrepreneurship as a continuum and Carland Entrepreneurship Index - CEI is an instrument which demonstrates the continuous nature of entrepreneurship. According to Carland's categorization of entrepreneurs, three categories emerge for determining the level of entrepreneurial drive. These are "Macro Entrepreneurs", "Micro Entrepreneurs" and "Entrepreneurs".

A "Macro Entrepreneur" will view his or her enterprise as a means to change the industry and become a dominant force. According to them, success is measured in terms of growth and profit in the business. They perceive their interest with their businesses as the primary vehicle for pursuing self-actualization. Since their drive for self-actualization is closely attached with their ventures, they measure their success in terms of growth and profits. Macro-Entrepreneurs are highly innovative and creative and constantly try to find new ways to realize their dreams: into new products, new markets, new industries, new heights of growth; into new challenges, new frontiers, new expressions, and new insights.

On the other end of the spectrum, we have Micro Entrepreneurs, who create businesses which never grow, but which become fixed as a landmark in our towns, cities and communities. Micro Entrepreneurs have a much lower level of entrepreneurial drive than do Macro Entrepreneurs and unlike Maco Entrepreneurs; they pursue self-actualization through some activity outside their businesses. According to them, their business ventures are the primary source for family income or to establish family employment, but they neither expect nor strive to become anything but a family owned business. When the MicroEntrepreneur reaches a self-assigned level of comfort, which generally equates to being able to support their needs, they feel successful and the focus of their lives shifts elsewhere. They do not pursue innovative or creative approaches to business and prefer safer and tried techniques. For these people, success means freedom. Having their own businesses liberates them from the pressures and demands of a career in management while it provides theirfamilies with financial support.

Between Macro and Micro Entrepreneurs, "Entrepreneurs" have a great deal of self-perception related with their businesses or positions, but they do not have 
much entrepreneurial drive as do Macro-Entrepreneurs have. Their interest in profits and growth is beyond that of Micro-Entrepreneurs but as soon as they achieve the level of success they require, they will shift focus to interests outside the business, just like Micro-Entrepreneurs. Entrepreneurs are innovative, but they are more likely to pursue enhancements to established products, services and procedures, rather than seek totally new approaches. Enhancements are safer and less likely to disrupt the steady climb to perceived success which is so important to Entrepreneurs. They want to realize their dreams of recognition and advancement, dreams of wealth and admiration.

CEI consists of 33 forced choice questions, and results in a scaled score which can be interpreted as a representation of the strength of one's entrepreneurship. CEI was designed by Carland's in order to produce a concrete measure of the strength of entrepreneurial drive, the drive to create a business venture, in an individual.

Carland (2001) considers entrepreneurship as a continuum on which businessmen can be categorized as "micro entrepreneur", "macro entrepreneur" and "entrepreneur". In this study, the subjects whose CEI varies from 0 and 15 are labeled as "Micro Entrepreneurs", who receive a CEI between 16 and 25 were the "Entrepreneurs" and the "Macro Entrepreneurs" are the ones whose CEl are between 26 and 33 .

\section{RESULTS}

The sample size of the study is 452 including 15 female (3,3\%) and 436 male $(96,7 \%)$ entrepreneurs. The age range varies between 20 and 84 with a mean of 45,26 and a standard deviation of 9,708 with an unanswered rate of $7,3 \%$. The education level of the sample is approximately between high school $(23,7$ $\%)$ and university (58,0 \%). $8,6 \%$ of the sample is graduates of primary and secondary school and $8,2 \%$ of the sample is having a master's or doctoral degree. In terms of marital status, most of the sample is married with a percentage of $92 \%$.

Apart from personal questions in the questionnaire, there were also questions related with the business life and the enterprises of the businessmen. In order to distinguish the "founders" and "non-founders", the businessmen were asked whether they founded the business or inherited it. The results showed a moderate distribution; while the percentage of founders were $45,8 \%$ and nonfounders' percentage of 48,7 . The number of the enterprises owned by the businessmen varies from 1 and 41 with a mean of 2,5 enterprises. As it can be observed in Table 1, most of the businessmen own one enterprise with a percentage of $37,5 \%$. 
Table 1: Frequency of the Enterprises Owned by the Businessmen

\begin{tabular}{|l|r|r|r|r|} 
& Frequency & $\begin{array}{c}\text { Percent } \\
\text { (\%) }\end{array}$ & $\begin{array}{c}\text { Valid } \\
\text { Percent } \\
(\%)\end{array}$ & $\begin{array}{c}\text { Cumulative } \\
\text { Percent } \\
(\%)\end{array}$ \\
\hline Owner of one enterprise & 139 & 30,8 & 37,5 & 37,5 \\
\hline Owner of two enterprises & 120 & 26,5 & 32,3 & 69,8 \\
\hline $\begin{array}{l}\text { Owner of three and more } \\
\text { enterprises }\end{array}$ & 112 & 24,8 & 30,2 & 100,0 \\
\hline Missing & 81 & 17,9 & & \\
\hline TOTAL & 452 & 100,0 & 100,0 & \\
\hline
\end{tabular}

The number of the employees working for the businessmen is between 1 and 7500 and the mean is 187. This question is also important for learning the size of the enterprises that are owned by the businessmen. According to the employee size classification of the World Bank, companies which have 1 and 50 employees are called as small enterprises, 51 and 200 employees as medium enterprises and more than 200 employees as large enterprises. In terms of this classification, $52,4 \%$ of the businessmen in the sample are small enterprise owners, $23,5 \%$ of them are medium sized enterprise owners and $16,4 \%$ of them have large enterprises. $7,7 \%$ of the businessmen did not answer this question.

Yearly revenues of the businessmen from their companies are categorized as; $17 \%$ of the enterprises' revenue is less than 1 million $\$, 21,7 \%$ of them are between 1 and 10 million $\$$ and $13,5 \%$ of them are more than 10 million $\$$. Most of the businessmen $(47,8 \%)$ preferred not to answer this question.

In Table 2, the descriptive statistics of the CEI and entrepreneurial traits of internal locus of control, need for achievement, innovativeness and risk taking propensity are summarized. Different from CEI, for all of the scales determining the personal traits, the lower scores mean higher and higher scores mean lower personal traits since the answers range from "1- Strongly Agree 2-Agree, 3Neither Agree nor Disagree, 4- Disagree, 5-Strongly Disagree". For CEI, higher scores should be interpreted as higher entrepreneurial level. From the table, it can be inferred that the sample is high in entrepreneurial level with a mean score of 20,75 . When 3 is considered to be the midpoint of the scales, the sample can be interpreted to have more internal rather than external locus of control (mean=2,27), high need for achievement (mean=2,47), high innovativeness (mean=2,49) and low risk taking propensity (mean=3,20). 
MEASURING THE ENTREPRENEURIAL LEVEL OF THE BUSINESSMEN:

THE RELATIONSHIP BETWEEN PERSONAL TRAITS AND ENTREPRENEURIAL LEVEL

Table 2: Descriptive Statistics of the Variables

\begin{tabular}{|l|r|r|r|r|r|r|}
\hline & $\mathrm{N}$ & Minimum & Maximum & Mean & $\begin{array}{r}\text { Standard } \\
\text { Deviation }\end{array}$ & T statistics* \\
\hline $\begin{array}{l}\text { Carland } \\
\text { Entrepreneurship }\end{array}$ & 451 & 6,00 & 30,00 & 20,75 & 3,845 & $20,709^{\star *}$ \\
\hline $\begin{array}{l}\text { Index - CEI } \\
\text { Internal Locus of }\end{array}$ & 450 & 1,00 & 4,00 & 2,27 &, 517 & $-30,024^{\star *}$ \\
\hline $\begin{array}{l}\text { Control } \\
\text { Need for }\end{array}$ & 450 & 1,08 & 3,75 & 2,47 &, 362 & $-30,856^{\star *}$ \\
\hline $\begin{array}{l}\text { Achievement } \\
\text { Innovation }\end{array}$ & 451 & 1,13 & 3,75 & 2,49 &, 428 & $-25,308^{* *}$ \\
\hline $\begin{array}{l}\text { Risk Taking } \\
\text { Propensity }\end{array}$ & 447 & 1,00 & 4,67 & 3,20 &, 557 & $7,707^{\star *}$ \\
\hline
\end{tabular}

* One sample t-teststatistics: In order to understand if the sample's mean of the variables differ from the mid point of the scales, which is 3 . (for CEI, mid-point is 17) Negative signs indicate that mean of the variables is significantly lower than the mid point. (Please note that higher scores mean lower personal traits)

${ }^{* *} p=, 000$

In the Table 3 below, the categorization of the Turkish businessmen, according to Carland's Entrepreneur categories, is given in frequency and percentages. As it can be seen, there is a normal distribution in which $81,6 \%$ of the businessmen fall into the medium category of "entrepreneurs". These results indicate that, most of the Turkish businessmen have much self-motivation related with their businesses. They are beyond just being a businessman but they do not have very high entrepreneurial drive and innovativeness.

Table 3: Distribution of the Businessmen according to Carland's Categorization of Entrepreneurs

\begin{tabular}{|c|c|c|c|c|}
\hline & Frequency & $\begin{array}{l}\text { Percent } \\
(\%)\end{array}$ & $\begin{array}{l}\text { Valid } \\
\text { Percent } \\
(\%)\end{array}$ & $\begin{array}{c}\text { Cumulative } \\
\text { Percent } \\
(\%)\end{array}$ \\
\hline Micro entrepreneurs & 44 & 9,7 & 9,8 & 9,8 \\
\hline Entrepreneurs & 369 & 81,6 & 81,8 & 91,6 \\
\hline Macro entrepreneurs & 38 & 8,4 & 8,4 & 100,0 \\
\hline Missing & 1 & ,2 & 100,0 & \\
\hline TOTAL & 452 & 100,0 & & \\
\hline
\end{tabular}

Table 4 provides the correlations of variables in which it can be observed that the dependent variable CEI is significantly positively correlated with all the independent variables of entrepreneurial personal traits other than internal locus of control. It can be stated that as the person's need for achievement, level of innovativeness and risk taking propensity increase, person's entrepreneurial level also increase. Internal locus of control is significantly positively correlated 
with need for achievement and innovativeness. All of the other personal traits are closely associated with each other $(p<, 01)$.

Table 4: Correlations of Carland Entrepreneurship Index (CEI) and Entrepreneurial Personal Traits

\begin{tabular}{|l|r|r|r|r|r|}
\hline & \multicolumn{1}{|c|}{1} & \multicolumn{1}{|c|}{2} & 3 & 4 & 5 \\
\hline 1-Carland Entrepreneurship Index - CEI & - & & & & \\
\hline 2-Internal Locus of Control &, 081 & - & & & \\
\hline 3-Need for Achievement &, $173^{*}$ &, $304^{*}$ & - & & \\
\hline 4-Innovation &, $371^{*}$ &, $122^{*}$ &, $345^{*}$ & - & \\
\hline $\begin{array}{l}\text { 5-Risk Taking Propensity } \\
{ }^{\mathrm{p}} \mathrm{p}<, 01\end{array}$ &, $270^{*}$ &, 056 &, $276^{*}$ &, $390^{*}$ & \\
\hline
\end{tabular}

In the analysis of mean comparison of all the variables in terms of personal and enterprise related demographical variables, significant differences were found. We did not compare the variables in terms of gender because the sizes of the groups were unequal. However, according to the age groups; $C E I$, nAch and innovativeness showed significant differences. According to One-Way ANOVA, the age groups of businessmen being younger than 40 (CEI=21,38), between 41 and $50(\mathrm{CEI}=20,90)$ and older than $51(\mathrm{CEI}=19,79)$ are significantly different in terms of $\operatorname{CEI}[F(2,415)=5,578, p=, 004]$. In terms of nAch, businessmen being younger than $40(\mathrm{nAch}=2,41)$, between 41 and $50(\mathrm{nAch}=2,51)$ and older than $51(\mathrm{nAch}=2,46)$ are significantly different $[\mathrm{F}(2,414)=3,181, \mathrm{p}=, 043]$. In addition, innovativeness level in businessmen younger than 40 (Innov=2,44), between 41 and $50 \quad($ Innov=2,45) and older than $51($ Innov=2,60) showed significant differences $[F(2,415)=5,609 p=, 004]$. In terms of education, CEI revealed no significant difference although we gathered significant results in innovativeness and risk taking propensity at the significance level of $p=, 10$. Innovativeness was observed to be highest in the businessmen having master's and doctoral degrees (Innov=2,43) and lowest in primary / secondary school and college graduates $(\operatorname{Innov}=2,55)[F(2,441)=2,883, p=, 057]$. Moreover, businessmen having low level of education found to have lowest level of risk taking propensity (Risk=3,26), while the ones having the highest degree in education had the highest degree of risk taking behavior (Risk=3,04) $[F(2,437)$ $=2,457, p=, 087]$.

According to the number of enterprises owned by the businessmen, significant results were found. Entrepreneurship level was found to be significantly different between the businessmen who have one enterprise and 3 and more enterprises $[F(2,367)=3,824, p=, 023]$. CEI score is highest in businessmen who have 3 and more enterprises $(\mathrm{CEI}=21,78)$ and lowest in businessmen $(\mathrm{CEI}=20,51)$ who own just one enterprise. Parallel to this finding, businessmen having 3 and more enterprises (Innov $=2,38$ ) were the most innovative and the businessmen having one enterprise were the ones $($ Innov $=2,55)$ who have the least innovative level $[F(2,368)=5,393, p=, 005]$. 
The yearly revenues of businessmen showed significant differences just in entrepreneurship level. The businessmen whose revenues are higher than 10 million \$ had the highest entrepreneurship level $(\mathrm{CEI}=22,20)$ while the ones who have revenues lower than 1 million $\$$ had the lowest $(C E I=20,27)[F(2,233)$ $=5,160, p=, 006]$. According to the enterprise size, the results revealed that the entrepreneurship level is significantly different. The businessmen who have small enterprises $(\mathrm{CEI}=20,58)$ have significantly lower entrepreneurial level than the medium $(20,78)$ and large enterprise $(21,98)$ owners $[F(2,413)=3,186, p=$ ,042)].

Below in Table 5, a linear regression model is presented where the dependent variable is "entrepreneurial level". In this model, innovativeness and yearly revenue more than 1 million $\$$ compared to the revenue less than 1 million $\$(p<$ , 01 ); risk taking propensity and the reason of investment (create employment, contribute to the country's economy, gain status/power" compared to make profit/earn money) $(p<, 05)$ positively and significantly affect the entrepreneurial level. In this model, need for achievement and internal locus of control are found to have no effect on the entrepreneurial level.

Table 5: Linear Regression Model of Entrepreneurial Level

\begin{tabular}{|c|c|}
\hline Dependent Variable: Entrepreneurial Level (CEI) & Coefficients \\
\hline \multicolumn{2}{|l|}{ Continuous variables } \\
\hline Innovativeness & $2,385(3,912)^{* *}$ \\
\hline Risk taking propensity & $1,063(2,412)^{*}$ \\
\hline Need for achievement &, $136(0,187)$ \\
\hline Internal locus of control & ,258 $(0,531)$ \\
\hline \multicolumn{2}{|l|}{ Categorical variables } \\
\hline Reason of investment $†$ & $1,031(2,029)^{*}$ \\
\hline Yearly revenue†† & $1,331(2,716)^{\star *}$ \\
\hline Constant & $30,375(15,13)^{\star *}$ \\
\hline \multicolumn{2}{|c|}{$\begin{array}{l}\mathrm{N}=229 \quad \mathrm{R}^{2}=, 21 \mathrm{~F}(6,228)=9,977 \text { Prob }>\mathrm{F}=, 000 \\
{ }^{*} \mathrm{p}<, 05 \quad{ }^{* *} \mathrm{p}<, 01(\mathrm{~T} \text { statistics are in brackets) } \\
\text { †Create employment, contribute to the country's economy, gain status/power compared to make } \\
\text { profit/earn money } \\
\text { ††Yearly revenue more than } 1 \text { million } \$ \text { compared to yearly revenue less than } 1 \text { million } \$ \\
\text { (Normally higher scores mean lower personal traits, but to prevent the confusion, we deleted the } \\
\text { negative signs) }\end{array}$} \\
\hline
\end{tabular}




\section{CONCLUSION}

The purpose of the study was to indicate whether a relation exists between personality traits, which are risk taking propensity, nAch, internal locus of control and innovativeness and entrepreneurial drivelevel. We also tried to find the determinants of entrepreneurial level by running regression analysis. According to the correlational analysis of $\mathrm{CEI}$ and entrepreneurial personal traits, all of the variables (Innov $=, 371$, Risk $=, 270$, nAch $=, 173$ ) other than internal locus of control showed a significant positive association with CEI. Parallel to our findings, in Carland's study, Jackson's Risk Taking Propensity ( ,60), innovativeness $(, 54)$ and need for achievement $(, 51)$ revealed significant correlations with CEI (Carland, et al., 1997; 8). Different from our results, in a longitudinal study of 11 years, Hansemark (2003) found that achievement motivation had no predictive validity on the entrepreneurial activity, but the results of the study showed that locus of control had predictive validity only for the male entrepreneurs.

Since the sample does not contain the non-entrepreneurs, it was not possible to compare these variables. However, when we evaluate the findings of Carland, et. al.'s study (1998), the mean of CEI score of American entrepreneurs was 20,23 and Finnish entrepreneurs was 18,14 which enables us to claim that (with a mean score of 20,75) Turkish businessmen have more entrepreneurial drive than their Finnish and American counterparts.

The results of our study showed that; nAch (with Risk $=, 276$, with Innov $=, 345$ ), risk taking propensity (with Innov $=, 390$ ) and innovativeness are positively interrelated at a high significant level $(p=, 000)$. This can be interpreted as, while the level of achievement motivation and propensity of risk taking of the Turkish businessmen increases, their level of innovation also improves. Moreover, internal locus of control was found to be highly positively correlated with nAch $(, 304, p=, 000)$ and innovativeness $(, 122, p=, 010)$, which can be explained "as the Turkish businessmen feel they have more control over their environment, they become more achievement oriented and more innovative" (the opposite direction of the argument may also be valid). The non-existent correlation between internal locus of control and CEI can be attributed to the fact that Turkish businessmen do not perceive the entrepreneurial environment as controllable and they believe success in the business is a matter of luck (i.e. to found a business at the right time and right place) rather than a deserved accomplishment. In addition, the regulations of the government make Turkish businessmen more externally oriented in terms of locus of control, which results in the weak association of control belief and entrepreneurial drive.

The demographical variables also have an impact on the entrepreneurial level. It was a very unfortunate result of having a very small sample of female entrepreneurs that made the comparison analysis impossible. However, when we interpret the entrepreneurial level and traits due to age, it is not wrong to claim that as the businessmen get older, their level of entrepreneurship (CEI) 
and innovativeness decrease. Moreover, the achievement motive is at the highest level when the businessmen are in their middle ages. This result is as parallel to our expectation because when people are young they feel more powerful to start a new business and to work hard. However as they get older, other responsibilities prevent the entrepreneurs to devote their time and energy to their business. Educational level also influences innovativeness and risk taking propensity. As the level of education of Turkish businessmen increases, the level of innovativeness and risk taking were also increasing. This result is also within the expectations because innovativeness is related with having accumulation of knowledge that can be gained by education. This argument may be valid for risk taking since taking risks in a rational manner (i.e. calculating all the possibilities of investing money to a profitable business) can be achieved by education.

According to the results of the linear regression model, two of the personal traits that are innovativeness and risk taking propensity are found to be strong predictors of entrepreneurial level. The coexistence of these two personal traits, in an individual, may help the researchers to explain the entrepreneurial level and success of that individual in entrepreneurship. This finding is consistent with the study of Mueller and Thomas (2000; 64) who consider innovativeness (together with internal locus of control) as a vital component of entrepreneurial orientation. Although there are opposite findings about risk taking propensity claiming that growth oriented entrepreneurs are more risk avoidant (Miner and Raju, 2004; 3), risk taking is considered to be a significant differentiator between managers and entrepreneurs (Stewart and Roth, 2001; 86), positively correlates with entrepreneurship (Ahmed, 1985; 781) and affects entrepreneurial intentions (Zhao et al., 2005; 1265). Latter results are consistent with the findings of our study.

In terms of categorical demographical variables, entrepreneurs' investment reason of profit making/earning money is a negative predictor of entrepreneurial level. This result clearly indicates that if an entrepreneur has materialistic motivation in investing, s/he is less likely to be considered as an entrepreneur. The level of entrepreneurship increases when the entrepreneurs' motivation of investment is to create employment, contribute to the country's economy and gain status/power. In addition, as entrepreneurs' yearly revenue increases the level of their entrepreneurial level also increases. Yearly revenue can be considered as a performance measurement, thus we can conclude that the businessmen who perform more are more entrepreneurial, which is an expected result.

In order to sum up, findings that are reported in this study may serve as a guide to an interest to entrepreneurs' psychological traits in the academic field which serves for the teaching of entrepreneurship. The personal traits of innovativeness and risk taking propensity are useful and significant means to comprehend the entrepreneurial level and performance of the businessmen. Hansemark (2003; 301) claims that both need for achievement and locus of 
control are considered to be learned characteristics, which can change and can be developed over time. We can also consider the other traits as developing and can train potential entrepreneurs in terms of these traits in order to flourish successful entrepreneurship. Moreover, if the nascent entrepreneurs are leaded to make investments not just for profit making but for contributing to the society and self enhancement, this may sound as a contradiction but, they would be more entrepreneurial which in turn would increase their performance and earning in the long run.

\section{REFERENCES}

Ahmed, S. U. (1985). NAch, Risk-taking Propensity, Locus of Control and Entrepreneurship. Personality and Individual Differences. 6(6): 781-782.

Alpkan, L.; Keskin, H. and Zehir, C. (2002). Girişimcilik Hisleriyle Girişimcilik Potansiyeli Arasındaki İlişki: Gebze ve Civarındaki Girişimciler Üzerine Bir Saha Araştırması. 21. Yüzyılda KOBíler: Sorunlar, Fırsatlar ve Çözüm Önerileri Sempozyumu. Doğu Akdeniz Üniversitesi. 3-4 Ocak 2002.

Baron, R. A. (2000), Psychological Perspectives on Entrepreneurship: Cognitive and Social Factors in Entrepreneurs' Success. Current Directions on Psychological Science, 9(1): 15-18.

Bonnett, C. and Furnham, A. (1991). Who Wants to be an Entrepreneur? A Study of Adolescents Interested in a Young Enterprise Scheme. Journal of Economic Psychology. 12(3): 465-478.

Brandstatter H. (1997). Becoming an Entrepreneur - A Question of Personality Structure? Journal of Economic Psychology. 18: 157-177.

Brockhaus, R. H. (1975). IE Locus of Control Scores as Predictors of Entrepreneurial Intentions. Proceedings of the Academy of Management: 433435.

Brockhaus, R. H. (1980). Risk Taking Propensity of Entrepreneurs. Academy of Management Journal, 23(3): 509-520.

Bygrave, W. D. and Hofer, C. W. (1991). Theorizing about entrepreneurship. Entrepreneurship Theory and Practice, 16(2): 3-22.

Carland J. A.; Carland, J. W.; Nasi, S. and Nasi, J. (1998). Gender Differences Between Finnish and American Entrepreneurs: An Exploratory Study. Small Business Institute Directors' Association. Proceedings, 22nd National Small Business Consulting Conference (Santa Fe, New Mexico; Feb. 4-7).

Carland, J. W.; Hoy, F.; Boulton, W. R. and Carland, J. A. (1984). Differentiating Entrepreneurs From Small Business Owners: A Conceptualization. Academy of Management Review. 9(2): 354-359. 
Carland, J. W.; Carland, J. A. and Hoy, F. (1992) An entrepreneurship index: An empirical validation. Paper presented at the Babson Entrepreneurship Conference, Fontainebleau, France, July.

Carland, J. W.; Carland, J. A. and Koiranen, M. (1997). The Exportation of the American Model of Entrepreneurship: Reality or Illusion? A Comparative Trait Study of American and Finnish Entrepreneurs. Retrieved December 21, 2004 from http://www.usasbe.org/knowledge/proceedings/1997/P124Carland.PDF

Carland, J. W.; Carland, J. A. and Ensley, M. D. (2001). Hunting the Heffalump: The Theoretical Basis and Dimensionality of the Carland Entrepreneurship Index. Academy of Entrepreneurship Journal. 7(2): 51-83.

Ceylan, A. and Demircan, N. (2002). Girişimcilerin Başarı, Güç ve Yakın İlişki İhtiyaçlarının Kişilik Özellikleriyle İlişkisi Üzerine Düzce Bölgesi'ndeki KOBI’lerde Bir Araştırma. 21. Yüzyılda KOBí'ler: Sorunlar, Fırsatlar ve Çözüm Önerileri Sempozyumu. Doğu Akdeniz Üniversitesi. 3-4 Ocak 2002.

Chu, P. (2000). The Characteristics of Chinese Female Entrepreneurs: Motivation and Personality. Journal of Enterprising Culture. 8(1): 67-84.

Hansemark , O. C. (2003). Need For Achievement, Locus of Control and The Prediction of Business Start-Ups: A Longitudinal Study. Journal of Economic Psychology. 24: 301-319.

Hisrich R,; Langan-Fox J. and Grant, S. (2007). Entrepreneurship Research and Practice: A Call to Action for Psychology. American Psychologist. 62(6): $575-589$

Hisrich, R. D. (1986). The Woman Entrepreneur: A Comparative Analysis. Leadership \& Organization Development Journal. 7(2): 8-16.

Hisrich, R. D. (1990). Entrepreneurship / Intrapreneurship. American Psychologist, 45(2): 209-222.

Hull, D.; Bosley, J, and Udell, G. (1980). Reviewing the Heffalump: Identifying Potential Entrepreneurs by Personality Characteristics. Journal of Small Business Management. 18(1): 11-18.

Ibrayeva, E. S. (1999). Entrepreneurship in Transitionary Economics: Testing A Social Coginitive Model. Unpublished Dissertation for the Degree of Doctor of Philosophy. University of Nebraska.

Jennings, D. E. and Zeithaml, C. P. (1983). Locus of Control: A Review and Directions for Entrepreneurial Research. Proceedings of the 43rd Annual Meeting of the Academy of Management: 417-421. 
Johnson, B. R. (1990). Towards a Multidimensional Model of Entrepreneurship: The Case of Achievement Motivation and the Entrepreneur. Entrepreneurship Theory and Practice. Spring: 39-54.

Kets de Vries, M. F. R. (1977). The Entrepreneurial Personality: A Person at the Crossroads. Journal of Management Studies. February: 34-57.

Kuratko, D. F. and Hodgetts, R. M. (1998). Entrepreneurship: A Contemporary Approach. (Fourth Edition). Fort Worth: The Dryden Press.

Lee, D. Y. and Tsang, E.W. K. (2001). The Effects of Entrepreneurial Personality, Background and Network Activities on Venture Growth. Journal of Management Studies. 38(4): 583-602

Lumpkin, G. T. and Erdogan, B. (2004). If Not Entrepreneurship, Can Psychological Characteristics Predict Entrepreneurial Orientation?- A Pilot Study. The ICFAI Journal of Entrepreneurship Development. 1(1): 21-33.

McClelland, D. C. (1971), "The Achievement Motive in Economic Growth" in KILBY P., (Edt.), Entrepreneurship and Economic Development, New York: The Free Press.

Miner, J.B. and Raju, N. S. (2004). Risk Propensity Differences Between Managers and Entrepreneurs and Between Low- and High-Growth Entrepreneurs: A Reply in a More Conservative Vein. Journal of Applied Psychology. 89(1): 3-13

Mueller, S. L. and Thomas, A. S. (2000). Culture and Entrepreneurial Potential: A Nine Country Study of Locus of Control and Innovativeness. Journal of Business Venturing 16: 51-75.

Palmer, M. (1971). The application of psychological testing to entrepreneurial potential. California Management Review, 13 (3): 32-38.

Pillis, E. (1997). Predicting Entrepreneurial Intention: A Cross-Cultural Study. Allied Academies International Conference. Maui, Hawaii. October 14-17: 2249.

Rauch, A. and Frese, M. (2000). Psychological approaches to entrepreneurial success. A general model and an overview of findings. In C.L. Cooper and I.T. Robertson (Eds.), International Review of Industrial and Organizational Psychology (101-142). Chichester: Wiley.

Schmitt-Rodermund, E. (2004). Pathways to Successful Entrepreneurship: Parenting, Personality, Early Entrepreneurial Competence, and Interests. Journal of Vocational Behavior. 65: 498-518. 
MEASURING THE ENTREPRENEURIAL LEVEL OF THE BUSINESSMEN: THE RELATIONSHIP BETWEEN PERSONAL TRAITS AND ENTREPRENEURIAL LEVEL

Short, L. and Dunn, P. (2002). The Search for a Theory of Entrepreneurship, $\begin{array}{llll}\text { Retrieved November } & 20, & 2003 & \text { from }\end{array}$ http://www.sbaer.uca.edu/research/2002/asbe/papers/02asbe040.pdf

Stewart, W. H.; Carland, J. A., Carland, J. W., Watson, W. E. and Sweo, R. (2003). Entrepreneurial Dispositions and Goal Orientations: A Comparative Exploration of United States and Russian Entrepreneurs. Journal of Small Business Management. 41(1): 27-46.

Stewart, W.H, Jr. and Roth, P. L. (2001). Risk propensity difference between entrepreneurs and managers: A meta-analytic review. Journal of Applied Psychology. 86(1): 145-153.

Tuunanen, M. (1997). Finnish and US Entrepreneurs' Need for Achievement: A Cross-Cultural Analysis. Allied Academies International Conference. Maui, Hawaii. October 14-17, 1997: 9-21.

Utsch, A. and Rauch, A. (2000). Innovativeness and Initiative as Mediators Between Achievement Orientation and Venture Performance. European Journal of Work and Organizational Psychology. 9 (1): 45-62.

Zhao, H.; Seibert, S. E. and Hills, G. E. (2005). The Mediating Role of SelfEfficacy in the Development of Entrepreneurial Intentions. Journal of Applied Psychology. 90(6): 1265-1272. 